\title{
Studi Literatur Kritis Risiko Reputasi pada Manajemen Risiko Perbankan Syariah
}

\author{
Afrizal $^{1 *}$, Saparuddin Siregar ${ }^{2}$, Sugianto $^{3}$ \\ 1,2,3 Universitas Islam Negeri Sumatera Utara, Kabupaten Deli Serdang, Provinsi \\ Sumatera Utara, Indonesia.
}

\begin{abstract}
Abstrak. Reputasi adalah aset tak berwujud yang paling penting yang dimiliki bank. Reputasi mencerminkan keberhasilan bank dalam memenuhi harapan berbagai pemangku kepentingan. Mewujudkan reputasi adalah elemen kunci dari strategi organisasi, terutama perbankan. Setiap masalab penting yang berkaitan dengan operasional bank Syariab baik dari segi ketidakpatuhan produk keuangan secara Syariah atau keluhan pelanggan dapat merusak reputasi bank Syariah. Penelitian ini bertujuan untuk menganalisis determinan risiko reputasi dan dampaknya terhadap perbankan Syariah serta bagaimana implementasi manajemen risiko reputasi di perbankan Syariah. Penelitian ini menggunakan pendekatan studi literatur untuk menjawab tujuan penelitian sedangkan teknik analisis yang digunakan dalam penelitian ini analisis isi (content analysis). Temuan penelitian ini adalah reputasi bank Syariah lebih penting daripada bank konvensional karena sifat bisnisnya ditentukan oleh prinsip Syariah. Dengan demikian, bank Syariah diharapkan lebih memperhatikan manajemen risiko reputasi.
\end{abstract}

Kata kunci: Perbankan; Bank Syariab; Manajemen Risiko; Risiko Reputasi.

\begin{abstract}
Reputation is the most important intangible asset owned by a bank. Reputation reflects the success of the bank in meeting the expectations of various stakeholders. Creating reputation is a key element of organizational strategy, especially banking. Any important issues related to the operations of Islamic banks, whether in terms of non-compliance with Sharia financial products or customer complaints, can damage the reputation of Sharia banks. This study aims to analyze the determinants of reputation risk and its impact on Islamic banking and how to implement reputation risk management in Islamic banking. This study uses a literature study approach to answer the research objectives, while the analytical technique used in this study is content analysis. Thus, Islamic banks are expected to pay more attention to reputation risk management.
\end{abstract}

Keywords: Banking; Islamic Bank; Risk Management; Reputational Risk. 


\section{Pendahuluan}

Penurunan reputasi bank sebagai kegagalan bank dalam memitigasi risiko terutama risiko reputasi telah terjadi dalam industri perbankan di Indonesia. Suhardjanto \& Dewi (2011) menyebutkan beberapa kasus yang mencerminkan buruknya pengelolaan bisnis bank seperti praktik perbankan yang tidak sehat yang mengesampingkan tata kelola perusahaan, kurangnya transparansi yang dilakukan pihak manajemen kepada stakeholder, dan tugas dan tanggung jawab dewan komisaris selaku pengawas pelaksanaan tata kelola perusahaan pada perbankan belum dilaksanakan dengan baik. Kasus-kasus tersebut antara lain kasus kredit macet di Bank Summa (1992), laporan keuangan ganda yang dilakukan oleh Lippo Bank (2002), kasus L/C fiktif bank BNI (2003), pembekuan usaha Bank Global (2004), kasus Bank Century (2008) dan masih banyak kasus bank bermasalah lainnya. Dalam beberapa kasus kemerosotan kondisi bank diikuti dengan menurunnya kepercayaan masyarakat. Dalam beberapa kasus, dampak yang ditimbulkan cukup besar hingga menyebabkan bank dilikuidasi atau berpindah kepemilikan.

Beberapa kasus penurunan reputasi bank yang dialami perbankan yang berdampak pada risiko reputasi di beberapa negara (Azrak et al., 2016) seperti kegagalan yang terjadi pada lembaga keuangan Islam akibat hutang dan manajemen yang buruk (The Islamic Bank of South AfricaIBSA (1989, 1997), kegagalan kontrol dan manajemen dan peraturan (Ihlas Finans of Turkey $(1983,2001)$ dan Blom Bank, Lebanon versus Investment Dar, Kuwait, 2009). Fiordelisi et al (2014) menyebutkan kerugian operasional terjadi karena penipuan interna: UBS (2011), Société Générale (2010), Allied Irish Bank (2002), Barings (1995), dan Daiwa Bank Ltd (1995) dan penipuan eksternal: Republic NewYork Corp (2001) dan kegagalan sistem di Salomon Brothers (1992).

Laporan Delloite tahun 2014 menyatakan bahwa risiko reputasi menempati peringkat pertama sebagai faktor risiko yang menjadi perhatian manajemen. Potensi terjadinya risiko reputasi umumnya diawali dengan terjadinya kerugian operasional. Ketika kerugian yang timbul karena risiko reputasi lebih besar daripada kerugian yang disebabkan oleh kerugian operasional, saat itulah risiko reputasi terjadi (Heidinger \& Gatzert, 2018). Beberapa penelitian menunjukkan kerugian yang disebabkan oleh risiko reputasi secara umum lebih besar daripada kerugian yang ditimbulkan oleh risiko operasional (Cummins et al., 2004; Fiordelisi et al., 2014).

Bank Syariah (Islamic Bank) sebagai salah satu lembaga keuangan merupakan suatu industri yang erat kaitannya dengan kepercayaan konsumen. Tanpa kepercayaan konsumen, bank tidak dapat menjalankan usahanya. Bank bertanggung jawab untuk mengelola aset nasabahnya. (Fiordelisi et al., 2014). Bank juga merupakan lembaga yang dikenal sebagai risk taking entities. Selain ancaman krisis keuangan global, pengungkapan informasi bank dapat menjadi kerusakan reputasi bank (Oorschot, 2010). Oleh karena usaha bank selalu dihadapkan pada pengambilan risiko yang besar seperti dalam aktifitas pendanaan, perkreditan dan treasury, kemampuan bank dalam mengenali dan memitigasi segala risiko yang mungkin dihadapi harus dilakukan oleh bank termasuk bank syariah.

Risiko dalam konteks perbankan merupakan suatu kejadian potensial baik berupa risiko yang dapat diperkirakan maupun risiko yang tidak dapat diperkirakan. Setiap risiko tersebu akan berdampak negatif terhadap aktifitas pendapatan dan permodalan bank. Risiko- risiko tersebut tidak dapat dihindari, akan tetapi dapat dikelola dan dikendalikan. Bank Syariah sebagaimana lembaga perbankan umumnya memerlukan serangkaian prosedur dan metodologi yang dapat digunakan untuk mengidentifikasi, mengukur, memantau, dan mengendalikan risiko yang timbul dari kegiatan usaha, atau yang biasa disebut sebagai manajemen resiko (Karim, 2016). Masa depan Bank Syariah akan sangat bergantung pada kemampuannya dalam merespon perubahan dalam dunia keuangan. Fenomena globalisasi dan revolusi teknologi informasi membuat sektor keuangan menjadi semakin dinamis, kompetitif dan kompleks saat ini. Adanya tren pertumbuhan merger lintas segmen, akuisisi dan konsolidasi keuangan juga membaurkan risiko unik tiap segmen dari industri keuangan (Zainal, 2020).

Berdasarkan latar belakang masalah tersebut 
bahwa pentingnya bank Syariah dalam memitigasi risiko terutama risiko reputasi dalam kegiatan operasionalnya, penelitian ini mencoba menganalisis determinan risiko reputasi dan dampaknya terhadap perbankan Syariah. Penelitian ini juga membahas bagaimana implementasi manajemen risiko reputasi di perbankan Syariah.

\section{Tinjauan Literatur}

\section{Manajemen Risiko}

Literatur studi manajemen risiko di perbankan Syariah dipelopori cendikiawan seperti Khan (1997), Vogel dan Hayes (1998), Obaidullah dan Wilson (1999), Karim (1999) dan Khan dan Ahmad (2001). Mereka berpendapat bahwa bank Syariah tidak hanya menghadapi jenis risiko yang dihadapi bank konvensional tetapi juga mengidentifikasi risiko baru dan unik sebagai akibat dari kelas aset unik bank Syariah dan struktur kewajiban (Hasan, 2009).

\section{Peraturan Bank Indonesia Nomor} 13/23/PBI/2011 mengatur bahwa yang harus diungkapkan perbankan Syariah, yaitu: risiko kredit, risiko pasar, risiko likuiditas, risiko operasional, risiko hukum, risiko reputasi, risiko stratejik, risiko kepatuhan, risiko imbal hasil dan risiko investasi. Selain itu, manajemen risiko juga didefinisikan sebagai serangkaian metode dan prosedur yang digunakan untuk mengukur, mengidentifikasi, serta mengendalikan risiko yang timbul dari kegiatan usaha bank Syariah.

Hal tersebut senada dengan definisi manajemen risiko adalah serangkaian prosedur dan metodologi yang digunakan untuk mengidentifikasi, mengukur, memantau dan mengendalikan risiko yang timbul dari kegiatan bank. Esensi penerapan manajemen risiko adalah kecukupan prosedur dan metodologi pengelolaan risiko sehingga kegiatan usaha bank tetap dapat terkendali pada batas yang dapat diterima serta menguntungkan bank, namun mengingat perbedaan kondisi struktur pasar, ukuran serta komplesitas usaha bank tidak terdapat satu sistem manajemen risiko yang universal untuk seluruh bank sehingga setiap bank harus membangun sistem manajemen risiko sesuai dengan fungsi dan organisasi manajemen risiko pada bank (Zainal, 2020).
Kualitas penerapan manajemen risiko mencerminkan penilaian kecukupan sistem pengendalian risiko, yang menentukan efektivitas penerapan manajemen risiko bank terhadap prsinsip-prinsip penerapan menajemen risiko bank umum. Kualitas penerapan manajemen risiko terdiri atas tiga aspek yaitu: (a) Tata kelola risiko; (b) Kerangka manajemen risiko; dan (c) Kecukupan sistem pengendalian risiko (Al Arif, 2018). Sehingga Informasi risiko perusahaan digunakan sebagai alat pengambilan keputusan yang cermat dan tepat, untuk itu perusahaan diharapkan mampu mengelola pengungkapkan informasi terkait risiko yang pada suatu perusahaan. Informasi yang diungkapkan tidak hanya informasi yang bersifat positif, melainkan informasi yang bersifat negatif yang terkait dengan aspek risiko manajemen (Yanuardin, 2020).

\section{Risiko Reputasi}

Reputasi dipandang sebagai aset tidak berwujud dengan potensi penciptaan nilai (Little dan Little, 2000). Reputasi secara luas diakui sebagai salah satu aset perusahaan yang paling penting dan utama sumber keunggulan kompetitif, tetapi juga yang paling sulit untuk dilindungi. Perubahan dalam lingkungan, seperti pengembangan media global dan saluran komunikasi, serta mengurangi loyalitas pelanggan, mengekspos organisasi pada peningkatan risiko reputasi. Risiko reputasi juga lebih sulit untuk dikelola daripada risiko tradisional. Hal tersebut karena risiko reputasi bertumpu pada persepsi. Untuk sebuah organisasi, terdapat banyak hal yang dipertaruhkan dengan suatu persepsi negatif daripada dengan risiko tradisional lain karena reputasi adalah nilai tidak berwujud mereka yang dipertaruhkan. Nilai tak berwujud saat ini diperkirakan sekitar 70 persen dari nilai pasar perusahaan S\&P 500 (indeks yang terdiri dari 500 perusahaan terbesar perusahaan AS) (Heil, 2018).

Comité Européen des Assurances (CEA) dan Groupe Consultatif Actuariel Europeen (2007) mendefinisikan risiko reputasi sebagai risiko yang merugikan publisitas terkait praktik bisnis dan asosiasi perusahaan asuransi, apakah akurat atau tidak, akan menyebabkan hilangnya kepercayaan terhadap integritas institusi. Risiko reputasi dapat muncul dari risiko lain yang 
melekat dalam aktivitas organisasi. Risiko kehilangan kepercayaan para pemangku kepentingan, yang meliputi, antara lain, pelanggan yang ada dan potensial, investor, pemasok, dan pengawas.

Basel Committe on Banking Supervision (2009) mendefinisikan risiko reputasi sebagai risiko yang timbul karena persepsi negatif dari nasabah, mitra usaha, pemegang saham, atau regulator yang dapat mempengaruhi kemampuan bank untuk menjalankan bisnis atau menciptakan peluang bisnis baru dan kemampuan untuk memperoleh sumber pendanaan. Di Indonesia, regulator mendefinisikan risiko reputasi sebagai risiko akibat penurunan kepercayaan dari para pemangku kepentingan, dimana penurunan tersebut disebabkan oleh persepsi negatif terhadap bank (Otoritas Jasa Keuangan, 2016). Aturan terkait manajemen risiko reputasi tertuang dalam aturan terkait manajemen risiko yang wajib diterapkan oleh bank.

Sehingga dapat disimpulkan bahwa risiko reputasi terkait dengan memburuknya persepsi para pemangku kepentingan. Risiko reputasi didefinisikan sebagai risiko dari persepsi negatif dari berbagai konsumen, pesaing, pemilik modal yang dapat berdampak kemapuan suatu lembaga keuangan untuk menjaga keberadaanya kini atau nanti, hubungan bisnis, dan sumber pendanaan yang berkelanjutan (IFSB, 2014). Dalam konteks bank syariah, IFSB (2005) menyebutkan bahwa risiko reputasi yang lahir dari pelanggaran syariah, atau dari rumor tentang mereka, dapat menyebabkan hilangnya deposan dan pemangku kepentingan lainnya sehingga mempengaruhi posisi pasar, likuiditas, dan profitabilitas bank.

\section{Metodologi Penelitian}

Penelitian ini menggunakan pendekatan studi literatur untuk menjawab tujuan penelitian. Studi literatur yang dilakukan dalam penelitian ini merupakan suatu bentuk penelitian yang dilakukan dengan mengumpulkan artikel jurnal dengan tema sesuai dengan tujuan penelitian, yaitu meninjau definisi dan pentingnya penerapan manajemen risiko reputasi di bank Syariah. Objek dari penelitian ini merupakan artikel-artikel jurnal ilmiah yang tersedian daring dengan bantuan mesin pencari (search-engine) google scholar. Teknik analisis yang digunakan dalam penelitian ini analisis isi (content analysis). Tujuan dari suatu analisis konten adalah mencari tahu isi dan maksud suatu teks. Selain itu, nnalisis konten merupakan suatu teknik penelitian untuk menghasilkan deskripsi yang objektif dan sistematik mengenai isi yang terkandung dalam media yang diteliti (Zuchdi, 1993).

\section{Hasil dan Pembahasan}

Risiko reputasi di perusahaan terutama dalam lembaga keuangan juga telah menemukan gaungnya di disiplin keuangan Islam. Perkembangan ini telah menyebabkan pengakuan akan pentingnya mengelola risiko reputasi oleh bank Syariah. Misalnya, kesadaran akan Tuhan harus ditanamkan dan tercermin dalam semua aspek perilaku perbankan Islam, mulai dari hubungan internal, berurusan dengan pelanggan dan bank lain, kebijakan dan prosedur, praktik bisnis, hingga dan termasuk, aturan berpakaian, dekorasi, gambar, dan sebagainya, yang dalam satu atau lain cara mempengaruhi reputasi bank Syariah.

Berdasarkan hasil penelusuran literatur menggunakan bantuan google scholar dengan kata kunci "reputation risk, bank, Islamic bank" ditemukan 10 artikel jurnal yang relevan sebagai berikut: 
Tabel 1. Literasi Reputation Risk, Bank, Islamic Bank

\begin{tabular}{|c|c|c|c|c|}
\hline No. & Judul & Penulis & Tahun & Identitas Jurnal \\
\hline 1 & $\begin{array}{l}\text { Identifying operational risk } \\
\text { exposures in Islamic } \\
\text { banking. }\end{array}$ & Izhar, H. & 2010 & $\begin{array}{l}\text { Kyoto Bulletin of Islamic Area } \\
\text { Studies, 3(2), 17-53 }\end{array}$ \\
\hline 2 & $\begin{array}{l}\text { An analysis of reputational } \\
\text { risks in Islamic banks in } \\
\text { Malaysia with a proposed } \\
\text { conceptual framework. }\end{array}$ & $\begin{array}{l}\text { Azrak, T., Saiti, } \\
\text { B., \& Ali, E. R. } \\
\text { A. E. }\end{array}$ & 2016 & $\begin{array}{l}\text { Al-Shajarah: Journal of the } \\
\text { International Institute of } \\
\text { Islamic Thought and } \\
\text { Civilization (ISTAC), 21(3) }\end{array}$ \\
\hline 3 & $\begin{array}{l}\text { Impact of corporate image } \\
\text { and corporate reputation on } \\
\text { customer loyalty: A review. }\end{array}$ & Tang, W. W. & 2007 & $\begin{array}{l}\text { Management Science and } \\
\text { Engineering, 1(2), 57-62 }\end{array}$ \\
\hline 4 & $\begin{array}{l}\text { Social media, reputation risk } \\
\text { and ambient publicity } \\
\text { management. }\end{array}$ & Aula, P. & 2010 & $\begin{array}{l}\text { Strategy and Leadership, 38(6), } \\
43-49\end{array}$ \\
\hline 5 & $\begin{array}{l}\text { The Theory and Practice of } \\
\text { Islamic Management Style: } \\
\text { The Experience of Bank } \\
\text { Muamalat Indonesia, }\end{array}$ & $\begin{array}{l}\text { Hamidi, M. } \\
\text { Luthfi. }\end{array}$ & 2006 & $\begin{array}{l}\text { Review of Islamic Economics, } \\
10(2) \text {, pp. } 115-131 .\end{array}$ \\
\hline 6 & $\begin{array}{l}\text { Operational risk exposures } \\
\text { of Islamic banks }\end{array}$ & $\begin{array}{l}\text { Archer, S. and } \\
\text { Haron, A. }\end{array}$ & 2007 & $\begin{array}{l}\text { Islamic Finance: The } \\
\text { Regulatory Challenge, John } \\
\text { Wiley \& Sons, Singapore, pp. } \\
\text { 121-131. }\end{array}$ \\
\hline 7 & $\begin{array}{l}\text { Sharíah risk and corporate } \\
\text { governance of Islamic banks }\end{array}$ & Ginena, $\mathrm{K}$. & 2014 & $\begin{array}{l}\text { Corporate Governance: The } \\
\text { International Journal of } \\
\text { Business in Society, 14(1), 86- } \\
103\end{array}$ \\
\hline 8 & $\begin{array}{l}\text { Reputation risk and its } \\
\text { impact on the Islamic banks: } \\
\text { Case of the Murabaha. }\end{array}$ & $\begin{array}{l}\text { Haron, M. S., } \\
\text { Ramli, R., Injas, } \\
\text { M. M. Y., \& } \\
\text { Injas, R. A. }\end{array}$ & 2015 & $\begin{array}{l}\text { International Journal of } \\
\text { Economics and Financial } \\
\text { Issues, 5(4) }\end{array}$ \\
\hline 9 & $\begin{array}{l}\text { Risk management practices } \\
\text { in Islamic and conventional } \\
\text { banks of Bangladesh: A } \\
\text { comparative analysis. }\end{array}$ & $\begin{array}{l}\text { Rahman, M. M., } \\
\text { Rahman, M. A., } \\
\text { \& Azad, M. A. } \\
\text { K. }\end{array}$ & 2015 & $\begin{array}{l}\text { Asian Social Science, 11(18), } \\
153\end{array}$ \\
\hline 10 & $\begin{array}{l}\text { Board size, chief risk officer } \\
\text { and risk-taking in Islamic } \\
\text { banks: role of Shariah } \\
\text { supervisory board. }\end{array}$ & $\begin{array}{l}\text { Najwa, N. A., } \\
\text { Ramly, Z., \& } \\
\text { Haron, R. }\end{array}$ & 2020 & $\begin{array}{l}\text { Jurnal Pengurusan (UKM } \\
\text { Journal of Management), } 57 .\end{array}$ \\
\hline
\end{tabular}

Hasil analisis konten pada artikel-artikel jurnal rujukan tersebut dikategori sebagai berikut:

\section{Pertama, determinan risiko reputasi pada bank syariah}

Bank Syariah merupakan lembaga keuangan yang beroperasi sesuai dengan aturan Syariah. Sebagai lembaga yang mengadopsi nilai-nilai Islam, Bank Syariah harus selalu menjunjung tinggi nilai-nilai Syariah. Hal ini sangat diperlukan agar perbedaan antara bank Syariah dengan praktik konvensional dapat dilihat dan dirasakan. Apabila masyarakat melihat bahwa suatu Bank Syariah tidak sesuai syariah, maka mereka bisa berdebat bahwa Bank Syariah tidak berbeda dengan bank konvensional. Konsekuensinya bisa sangat menghancurkan dan setidaknya merusak reputasi lembaga keuangan Islam tersebut (Izhar, 2010). Dalam teori risiko reputasi, lembaga biasanya menekankan pentingnya tindakan. Belajar sambil melakukan 
telah menjadi salah satu elemen kunci dalam pengelolaan risiko reputasi, khususnya bagi bank Syariah di mana risiko reputasi lebih berat di bank Syariah daripada di bank konvensional. Hal tersebut dikarenakan orang tidak hanya melihat aspek operasional, tetapi juga pada aspek keagamaan/ kesyariahannya. Risiko ketidakpatuhan Syariah dianggap sebagai penyebab utama reputasi risiko bagi bank Syariah. Hal tersebut dikarenakan banyak nasabah yang bertransaksi dengan Bank Syariah dalam produk dan layanan keuangannya, mereka mengharapkan kepada bank untuk memenuhi mandat mereka dalam hal kepatuhan Syariah. Hingga batas tertentu, nasabah Bank Syariah mengharapkan bank untuk mematuhi prinsipprinsip yang dianut oleh syariah dalam hal keadilan dan transparansi dalam bertransaksi. Ada beberapa contoh kegagalan suatu Bank Syariah dalam menawarkan produk keuangan syariahnya. Kegagalan reputasi tersebut dapat berdampak pada bank Syariah lain yang menawarkan produk dan layanan serupa. Sehingga bagaimana masalah tersebut dapat dihindari atau dikurangi untuk menghindari setiap kerugian risiko reputasi. Selain itu, ada beberapa tuduhan ketidakpatuhan Syariah yang dibuat terhadap beberapa orang Islam terkait suatu layanan dan produk keuangan (Azrak et al., 2016).

Dalam industri pelayanan seperti perbankan, hubungan antara reputasi perusahaan dan sebuah daya tawar lebih sulit dikendalikan karena layanan yang tak berwujud. Dari perspektif ini, karakter yang tidak berwujud lainnya seperti penyedia layanan mungkin digunakan untuk membuat reputasi mereka lebih mudah terlihat. Dalam pengaruhnya terhadap perilaku konsumen, organisasi layanan harus memberdayakan pendapat berdasarkan kontak personal dan lingkunan fisik yang dimana konsumen merupakan elemen menegaskan keuntungan yang menjanjikan dalam transaksi layanan jasa (Tang, 2007)

Selain layanan jasa, peran sosial media seperti jaringan sosial, pembuatan konten, distribusi layanan dan website perusahaan secara bersamasama digunakan oleh pengguna, layanan video dan foto, dunia virtual dan website pihak ketiga. Dari perpektif perusahaan, layanan media sosial yang paling menarik dan paling popular di layanan media sosial yaitu Facebook, MySpace, LinkedIn, dan Twitter. Sosial media juga membentuk ekspektasi atau kepercayaan baru mengenai perusahaan. Risiko reputasi dapat merupakanhasil dari aktivitas komunikasi termasuk umpan balik dalam mengklaim keberadaannya di dalam media sosial. Dalam media sosial, perusahaan tidak boleh tidak harus nampak baik, tetapi harus terlihat baik. Manajemen risiko reputasi harus dimulai sebelum dan bukan setelah krisis reputasi. Manajemen suasana publisitas memegang peranan penting dalam mambangun hubungan yang strategis dengan stakeholder, mecerminkan keinginan mereka memhasilkan reputasi perusahaan yang baik, dan secara utama membangun nilai untuk perusahaan dengan meningkatkan dan mempertahankan sebuah reputasi yang baik (Aula, 2010). Terakhir, variabel profit, ukuran perusahaan dan kecukupan modal (Capital Adequate Ratio/ CAR) tidak berpengaruh pada risiko reputasi bank syariah. Hal tersebut dibutuhkan penelitian lebih lanjut mengenai risiko reputasi yang sampai saat ini belum pasti dapat dikuantifikasi (Nisa \& Nawasiah, 2020).

\section{Kedua, dampak risiko reputasi terhadap perbankan Syariah}

Kegagalan bank dalam mempertahankan tanggung jawab fidusia akan mengakibatkan kemerosotan reputasi bank Syariah. Kerusakan reputasi pada akhirnya dapat menyebabkan penarikan dana yang akan mengakibatkan krisis likuiditas. Hal tersebut juga dapat membuat nasabah berhenti melakukan pembiayaan dari bank syariah hingga memicu penurunan pendapatan profitabilitas. Penelitian menyarankan bank syariah perlu melakukan dua hal: pertama, memastikan bahwa produk keuangan mereka sesuai Syariah, kedua, mempertahankan peran fidusia secara efektif (Hamidi, 2006).

Bank Syariah tidak akan kehilangan kredibilitas sepanjang mematuhi kepatuhan syariah dalam kegiatan mereka karena kredibilitas adalah inti dari bisnis mereka (Archer \& Haron, 2007). Reputasi juga merupakan aset berharga khusus untuk industri keuangan Islam. Reputasi Bank Syariah sifat khusus dalam menarik pelanggan 
dan para pemangku kepentingan (Askari, et al., 2011).

Risiko syariah, sebuah risiko operasional menyebabkan bahaya kepercayaan terhadap bank syariah dan pemangku kepentingannya. Konsekuensi yang mungkin dari ketidakpatuhan Syariah diantaranya adalah biaya operasional yang tinggi, kehilangan keuangan, masalah likuiditas, kebangkrutan bank, hingga ketidakstabilan industri keuangan secara umum (Ginena, 2014). Risiko reputasi juga merupakan kategori risiko operasional lainnya yang muncul dari menurunnya kepercayaan nasabah terhadap Bank Syariah karena tindakan yang tidak bertanggungjawab atau perilaku salah urus manajemen. Risiko reputasi dekat kaitannya dengan risiko fidusia dan ketidakpatuhan syariah. Selain itu, publisitas negatif dapat membawa dampak yang signifikan terhadap pangsa pasar, profitabilitas dan likuditas bank Syariah (Abdullah et al., 2011).

Pemantauan risiko yang efektif dan efisien memastikan bahwa setiap lembaga keuangan Islam dilindungi dari efek buruk dari risiko reputasi. Risiko reputasi dan jenis manajemen risiko lainnya dianggap serius di Tabung Amanah Islam Brunei (TAIB). Pengelolaan risiko reputasi di Tabung Amanah Islam Brunei beserta pemahaman dan kesadaran di antara stafnya (Bashir et al., 2015).

\section{Ketiga, implementasi manajemen risiko reputasi di perbankan Syariah}

Manajemen risiko adalah salah satu praktik yang digunakan oleh bank untuk mengurangi berbagai macam risiko. Seperti perbankan konvensional, perbankan Syariah menghadapi berbagai risiko penting, meskipun pendekatan yang digunakan dalam perbankan Syariah sangat berbeda. Singkatnya, karakteristik unik dan sifat perbankan syariah, khususnya pendekatan bagi hasil ke perbankan, benar-benar mengubah seberapa besar risiko yang mereka hadapi. Selanjutnya, dibandingkan dengan perbankan konvensional, bank Syariah berurusan dengan banyak produk yang tidak ditemukan di perbankan konvensional, dengan risiko yang unik dan terkadang signifikan. Dengan demikian sangat penting bagi bank Syariah untuk menggunakan teknik manajemen risiko untuk memitigasi risiko (Rahman et al., 2015).

Bank Syariah dapat membangun strategi meningkatkan citra dan reputasi bank. Citra bank syariah memegang peranan paling penting dalam kepuasan konsumen/ nasabahnya. Bank Syariah harus menyakinkan retensi konsumen yang ada dan menarik konsumen baru yang terpuaskan dengan layanan dan produk bank syariah. Faktor citra dan reputasi terbukti sebagai sebuah kriteria penting dalam memutuskan layanan perbankan yang juga secara simultan mengarah kepada kepuasan nasabah (Hamzah et al., 2015).

Risiko reputasi sebagai salah satu risiko terpenting dalam industri dan pasar yang kompetitif. Manajemen reputasi yang sukses membutuhkan pemahaman sifat dan metode pengukurannya, sama baiknya dengan mengidentifikasi stimulus dalam pengembangan reputasi dan memahami faktor-faktor apa saja yang yang berperan dalam menciptakan dan membangun kembali reputasi. Perusahaan dengan net profit margin (NPM) dan return on asset (ROA) yang baik tidak terdampak risiko reputasi tersebut. (Roodphosti et al., 2018).

Isu-isu mengenai produk murabahah dalam perbankan Syariah memiliki hubungan dengan risiko reputasi dan risiko ketidakpatuhan dan berdampak pada stabilitas dan kinerja keuangan perbankan Syariah. Perbankan Syariah sama seperti semua perusahaan lain, dipengaruhi oleh reputasi risiko, meskipun prinsip-prinsip mereka didasarkan pada ajaran Islam. Bank Syariah harus membuat sebuah departemen terkait yang merupakan bagian dari manajemen risiko dalam memitigasi risiko reputasi, memonitoring, dan mengatasinya. Bank Syariah juga harus membangun badan supervise yang kuat. Dan terakhir, bank syariah harus meningkatkan kesadaran nasabah itu sendiri dengan produk dan layanan bank syariah. Sehingga bank syariah percaya diri dan mampu menjaga loyalitas nasabahnya dalam menghindari risiko ketidakpatuhan (Haron et al., 2015)

Risiko reputasi dalam bank Syariah erat kaitannya dengan ketidakpatuhan bank dalam menjalankan kegiatan operasional bank sesuai Syariah terutama dalam layanan pendanaan dan pembiayaan berbasis akad-akad Syariah. Selain 
ketidakpatuhan Syariah, risiko fidusia menjadi faktor lain yang meningkatkan risiko reputasi bagi bank Syariah. Faktor determinan internal tersebut dikuatkan oleh faktor determinan ekternal yaitu kepuasan nasabah/ konsumen terhadap layanan bank Syariah. Ketidakpuasan konsumen menyebabkan publisitas bank Syariah yang negatif dan berakibat penarikan dana nasabah hingga menurunya kepercayaan investor dalam pembiayaan terhadap bank Syariah.

Risiko reputasi ini memang sulit diukur dengan suautu ukuran keuangan tertentu. Beberapa faktor determinasi keuangan seperti return of asset (ROA), tingkat profitabilitas, net profit margin (NPM), dan kecukupan modal/ Capital Adequate Ratio (CAR) membutuhkan penelitian lebih lanjut mengenai pengaruhnya terhadap risiko reputasi. Faktor determinasi non-keuangan lainnya yang dapat mempengaruhi risiko reputasi bank syariah yaitu pengaruh media sosial seperti facebook, twitter, instagram yang saat ini menjadi trend khusus dalam membentuk citra yang harus baik bank syariah baik di mata konsumen hingga pemegang kepentingan lainnya.

Sebagaimana paparan riset-riset dalam penelitian ini, risiko reputasi merupakan risiko reputasi sebagai risiko yang timbul karena persepsi negatif dari nasabah, mitra usaha, pemegang saham, atau regulator yang dapat mempengaruhi kemampuan bank untuk menjalankan bisnis. Risiko reputasi tersebut merupakan bagian risiko operasional terutama bank Syariah yang melandasi kegiatan operasionalnya berdasarkan prinsip-prinsip Syariah tidak hanya akad-akad transaksi saja, akan tetapi kepada kegiatan operasional bisnis. Nilai-nilai Syariah menjadi business core bank Syariah yang tidak hanya menjadi keunggulan bersaing, tapi juga menjadi tantangan untuk menjaga seluruh kegiatan operasional sesuai Syariah. Hal tersebut karena reputasi atau citra perusahaan merupakan aset yang tidak berwujud terutama bank Syariah.

Manajemen risiko reputasi di perbankan Syariah harus membentuk suatu unit atau departemen tertentu, yang merupakan bagian dari manajemen risiko untuk memoderasi, pemantauan dan kewaspadaan bagi manajemen atas risiko reputasi. Pengawasan internal dalam pemenuhan kepatuhan Syariah baik akad dan operasional menjadi suatu upaya mitigasi risiko reputasi yang diperlukan dalam bank Syariah. Layanan konsumen menjadi faktor utama dalam memitigasi risiko reputasi terutama bank Syariah sudah mengaplikasikan berbagai media sosial sebagai channel pelayanan yang cepat dan efisien. Ketidakpuasan nasabah atas suatu layanan bank syariah semestinya ditanggapi secara cepat dan dianggap suatu hal yang serius untuk segera diselesaikan. Keaktifan bank Syariah dalam mengelola media sosialnya bukan hanya untuk membentuk publisitas yang baik juga mereduksi citra negatif yang timbul dari berbagai keluhan nasabah yang tidak terselesaikan.

Selain itu, pengelolaan risiko reputasi sebagai suatu prioritas yang mutlak dalam menyusun kebijakan risiko reputasi internal dan menguraikan proses rinci untuk mengelola risiko reputasi. Kebijakan ini memerlukan peran dan tanggung jawab dalam organisasi, termasuk Anggota Komite Syariah, Dewan Direksi dan Manajemen. Dewan Direksi harus terlibat langsung dalam pengendalian dan pengelolaan risiko reputasi, dengan bimbingan dan saran dari Komite Syariah terutama yang berkaitan dengan risiko ketidakpatuhan Syariah, karena hal ini sebagai penyebab paling kritis untuk risiko reputasi di bank Syariah.

\section{Kesimpulan}

Risiko reputasi merupakan risiko yang timbul karena persepsi negatif dari nasabah, mitra usaha, pemegang saham, atau regulator yang dapat mempengaruhi kemampuan bank dalam menjalankan bisnis termasuk bank Syariah di mana kegiatan operasionalnya berdasarkan prinsip-prinsip syariah. Nilai-nilai syariah menjadi business core bank Syariah yang tidak hanya menjadi keunggulan bersaing, tapi juga menjadi tantangan untuk menjaga seluruh kegiatan operasional sesuai Syariah. Bank Syariah tidak akan kehilangan kredibilitas sepanjang mematuhi kepatuhan Syariah dalam kegiatan mereka. Sebagaimana lembaga perbankan pada umumnya, bank Syariah juga memerlukan serangkaian prosedur dan metodologi yang dapat digunakan untuk mengidentifikasi, mengukur, memantau, dan mengendalikan risiko yang 
timbul dari kegiatan usaha, atau yang biasa disebut sebagai manajemen resiko. Pemantauan risiko yang efektif dan efisien memastikan bahwa setiap lembaga keuangan Islam dilindungi dari efek buruk dari risiko reputasi. Dalam mengelola risiko reputasi, adalah prioritas yang mutlak dalam menyusun kebijakan risiko reputasi internal dan menguraikan proses rinci untuk mengelola risiko reputasi. Kebijakan ini memerlukan peran dan tanggung jawab dalam organisasi, termasuk Anggota Komite Syariah, Dewan Direksi dan Manajemen.

\section{Daftar Pustaka}

Abdullah, M., Shahimi, S., \& Ismail, A. G. (2011). Operational in Islamic banks: Issues and management, Qualitative Research in Financial Markets 3 (2) 131-151. https://doi.org/10.1108/1755417111115 5366

Al Arif, M.Nur Rianto. (2018). Manajemen Risiko Perbankan syariah. Bandung: CV. Pustaka Setia

Aula, P. (2010). Social media, reputation risk and ambient publicity management. Strategy and Leadership, 38(6), 43-49. https://doi.org/10.1108/1087857101108 8069

Archer, S. and Haron, A. (2007). Operational risk exposures of Islamic banks, in Archer, S. and Abdel Karim, R. (Eds), Islamic Finance: The Regulatory Challenge, John Wiley \& Sons, Singapore, pp. 121-131

Azrak, T., Saiti, B., \& Ali, E. R. A. E. (2016). An analysis of reputational risks in Islamic banks in Malaysia with a proposed conceptual framework. Al-Shajarah: Journal of the International Institute of Islamic Thought and Civilization (ISTAC), 21(3), 331-360. Diakses dari https://journals.iium.edu.my/shajarah/i ndex.php/shaj/article/view/424
Basel Committee. (2009). Enhancements to the Basel II Framework. Basel, Switzerland, http://www.bis.org/publ/bcbs157.pdf, accessed: 11/11/2021

Bashir, M. S., Sulaiha, F., Shafeek, M., \& Machali, M. M. (2015). Reputation risk management in Islamic financial institutions: a case of Tabung Amanah Islam Brunei. International Journal of Economics and Management Studies, 2(3), 55 59. Diakses dari http://www.internationaljournalssrg.org/ IJEMS/paper-details?Id=30

Cummins, J. D., Lewis, C. M., \& Wei, R. (2004). The market value impact of operational loss events for US banks and insurers. Journal of Banking and Finance, 30(10), 2605-2634.

https://doi.org/10.1016/j.jbankfin.2005. 09.015

Deloitte. (2014). 2014 global survey on reputation risk Reputation, (October). Diakses dari https://www2.deloitte.com/content/dam /Deloitte/global/Documents/Governan ce-Risk-

Compliance/gx_grc_Reputation@Risk\% 20survey\%20report_FINAL.pdf

Economist Intelligent Unit. (2012). Reputational risk and IT in the banking industry. IBM Global Reputational Risk and IT Study Survey, (June). Dikases dari https:/ / fst.net.au/wpcontent/uploads/file/whitepaper/rlw030 10usen_3.pdf

Fiordelisi, F., Soana, M. G., \& Schwizer, P. (2014). Reputational losses and operational risk in banking. European Journal of Finance, 20(2), 105-124. https://doi.org/10.1080/1351847X.2012. 684218 
Ginena, K. (2014). Sharī'ah risk and corporate governance of Islamic banks. Corporate Governance: The International Journal of Business in Society, 14(1), 86-103. DOI 10.1108/CG-03-2013-0038

H. Askari, Z. Iqbal, \& A. Mirakhor,New Issues in Islamic Finance and Economics: Progress and Challenges (Vol. 753). (John Wiley \& Sons, 2011), 36

Hamidi, M. L. (2006). The Theory and Practice of Islamic Management Style: The Experience of Bank Muamalat Indonesia. Review of Islamic Economics, 10(2), pp. 115- 131. Diakses dari https://iaif.ir/images/khareji/articles/ba $\mathrm{nk} / 111 . \mathrm{pdf}$

Hamzah, N., Ishak, N. M., \& Nor, N. I. M. (2015). Customer satisfactions on Islamic banking system. Journal of Economics, Business and Management, 3(1), 140-144. DOI: 10.7763/JOEBM.2015.V3.170

Haron, M. S., Ramli, R., Injas, M. M. Y., \& Injas, R. A. (2015). Reputation risk and its impact on the Islamic banks: Case of the Murabaha. International Journal of Economics and Financial Issues, 5(4), 854-859. Diakses dari

http://www.econjournals.com/index.ph $\mathrm{p} /$ ijefi/article/download/1406/pdf

Hasan, A. (2009). Risk management practices of Islamic banks of Brunei Darussalam. The Journal of Risk Finance, 10(1), 23-37 DOI:10.1108/15265940910924472

Heidinger, D., \& Gatzert, N. (2018). Awareness, determinants and value of reputation risk management: Empirical evidence from the banking and insurance industry. Journal of Banking \& Finance, 91, 106-118.

https://doi.org/10.1016/j.jbankfin.2018. 04.004

Heil, D. (2018). Reputation Risk. The International Encyclopedia of Strategic Communication. DOI: 10.1002/9781119010722.iesc0150. pp. 16
Izhar, H. (2010). Identifying operational risk exposures in Islamic banking. Kyoto Bulletin of Islamic Area Studies, 3(2), 17-53. Diakses dari https://kias.asafas.kyotou.ac.jp/1st_period/contents/pdf/kb3_2/ 05hylman.pdf

Islamic Financial Services Board (2005), Guiding Principles of Risk Management for Institutions (Other Than Insurance Institutions) Offering Only Islamic Financial Services. IFSB: Kuala Lumpur.

Karim, A.A. (2016). Bank Islam: Analisis Figh dan Keuangan, Edisi Kelima, Jakarta : PT. RajaGrafindo Persada

Lee, L. F., Hutton, A. P., \& Shu, S. (2015). the role of social media in the capital market: Evidence from consumer product recalls. Journal of Accounting Research, 53(2), 367404. $\quad$ https://doi.org/10.1111/1475$\underline{679 X .12074}$

Little, P. \& Little, B. L. (2000) "Do perceptions of corporate social responsibility contribute to explaining differences in corporate priceearnings ratios? A research note," Corporate Reputation Rev., vol. 3, no. 2, p. 137-142, https://doi.org/10.1057/palgrave.crr.154 0108

Najwa, N. A., Ramly, Z., \& Haron, R. (2020). Board size, chief risk officer and risktaking in Islamic banks: role of Shariah supervisory board. Jurnal Pengurusan (UKM Journal of Management), 57.

Nisa, C., \& Nawasiah, N. (2020). Determinant Of Reputation Risk Management In Islamic Banks In Indonesia. Inquisitive: International Journal of Economic, 1(1), 1-13. Diakses dari http://journal.univpancasila.ac.id/index.p hp/INQUISITIVE/article/view/1857/1 104

Otoritas Jasa Keuangan. (2016). Penerapan Manajemen Risiko Bagi Bank Umum 
Omar, H. H. (2019). Harmonising Mudarabah Practices in Conventional Regulatory Regime In Tanzania. Diakses dari http:/ / eprints.utm.my/id/eprint/92317/ 1/HabibaHassanOmarPAHIBS2019.pdf. pdf

Van Oorschot, L. (2010). Risk Reporting: An Analysis of the German Banking Industry. Erasmus MC: University Medical Center Rotterdam. Diakses dari http://hdl.handle.net/1765/20027

Ott, L., \& Theunissen, P. (2015). Reputations at risk: Engagement during social media crises. Public Relations Review, 41(1), 97 102.

https://doi.org/10.1016/j.pubrev.2014.1 0.015

Rahman, M. M., Rahman, M. A., \& Azad, M. A. K. (2015). Risk management practices in Islamic and conventional banks of Bangladesh: A comparative analysis. Asian Social Science, 11(18), 153. DOI:10.5539/ass.v11n18p153

Rahnamay Roodposhti, F., Askari Firoozjaei, E., \& Rostami Noroozabad, M. (2018). Reputation Risk Management in the Framework of Enterprise Risk Management: Evidences from an Active Financial Institution in the Capital Market of Iran. International Journal of Finance \& Managerial Accounting, 3(10), 1-13. Diakses dari https://ijfma.srbiau.ac.ir/article_13325_ 95d940cf7e01833249d556b1d8c739fc.pd $\mathrm{f}$

Suhardjanto, D., \& Dewi, A. (2011). Pengungkapan Risiko Finansial Dan Tata Kelola Perusahaan: Studi Empiris Perbankan Indonesia. Jurnal Keuangan Dan Perbankan, 105(1). Diakses dari 105-118. https://jurnal.unmer.ac.id/index.php/jk $\mathrm{dp} /$ article/view/1005
Tang, W. W. (2007). Impact of corporate image and corporate reputation on customer loyalty: A review. Management Science and Engineering, 1(2), 57-62. Diakses dari http://cscanada.net/index.php/mse/artic le/view/j.mse.1913035X20070102.008/8 69

Yanuardin, Y. (2021). Studi Literatur Manajemen Risiko Hukum. At-Tazakki: Jurnal Kajian Ilmu Pendidikan Islam dan Humaniora, 4(1), 1-13. Diakses dari http://jurnal.uinsu.ac.id/index.php/attaz akki/article/view/7047

Zainal, V. R. (2020). Manajemen Risiko Bank Islam, Sidoarjo: Indomedia Pustaka. 